\title{
Paradoxical derbid-like planthopper (Homoptera: Fulgoroidea) from Cretaceous Burmese amber
}

\author{
Парадоксальный, похожкий на дербид фулгороид \\ (Homoptera: Fulgoroidea) из мелового бирманского янтаря
}

\author{
D.E. Shcherbakov ${ }^{1}$ A.F. Emeljanov ${ }^{2}$ \\ А.Е. Щербаков ${ }^{1}$, А.Ф. Емельянов ${ }^{2}$
}

\footnotetext{
${ }^{1}$ Borissiak Paleontological Institute, Russian Academy of Sciences, Profsoyuznaya St. 123, Moscow 117647, Russia. E-mail: dshh@narod.ru

2 Zoological Institute, Russian Academy of Sciences, Universitetskaya Emb. 1, St. Petersburg 199034, Russia.

E-mail: alexandr.emeljanov@zin.ru

${ }^{1}$ Палеонтологический институт им. А.А. Борисяка РАН, ул. Профсоюзная 123, Москва 117647, Россия.

2 Зоологический институт РАН, Университетская наб. 1, Санкт-Петербург 199034, Россия.
}

KEY WORDS: Hemiptera, Derbidae, wax, fossil, Mesozoic, inadaptive evolution.

КЛЮЧЕВЫЕ СЛОВА: Hemiptera, Derbidae, воск, ископаемые, мезозой, инадаптивная эволюция.

ABSTRACT. Inoderbe rapunzel gen. et sp.n. from mid-Cretaceous Burmese amber, representing a new planthopper family Inoderbidae fam.n., shows modifications of the head and wings parallel to those in the higher Derbidae, combined with venation features of the primitive Jurassic family Fulgoridiidae, antennae enlarged as in some Delphacidae, and luxuriant wax plumage reminiscent of some Fulgoridae.

РЕЗЮМЕ. Inoderbe rapunzel gen. et sp.n. из среднемелового бирманского янтаря, представитель нового семейства фулгороидов Inoderbidae fam.n., демонстрирует преобразования головы и крыльев, параллельные таковым высших Derbidae, в сочетании с признаками жилкования примитивного юрского семейства Fulgoridiidae, усиками, увеличенными как у некоторых Delphacidae, и пышным восковым плюмажем наподобие некоторых Fulgoridae.

Mid-Cretaceous Burmese amber, formed about 100 Myr ago on an island in the tropical ocean between Gondwana and Laurasia [Westerweel et al., 2019], contains a rich insect fauna [Ross, 2021]. Among speciose Burmite Fulgoroidea, there are four endemic families Dorytocidae, Yetkhatidae, Jubisentidae, Katlasidae [Emeljanov, Shcherbakov, 2018; Song et al., 2019, 2021; Luo et al., 2020; Shcherbakov, 2020], three widespread Cretaceous families - Perforissidae, Mimarachnidae, Neazoniidae [Shcherbakov, 2007; Fu, Huang, 2021; Olmi et al., 2021], three extant families Cixiidae, Achilidae, Derbidae [Shcherbakov, 2000; Szwedo, 2004; Emeljanov, Shcherbakov, 2020], and a few genera unassigned to the family [Luo et al., 2021].

A new find in Burmese amber, a unique planthopper showing a peculiar mixture of primitive and derived characters, is described below as a new family. The type specimen is deposited at Borissiak Paleontological Institute, Russian Academy of Sciences, Moscow (PIN). Photographs were taken using a Leica M165C stereomicroscope with a Leica DFC425 digital camera and zstacked with Helicon Focus 7.0.

Superfamily Fulgoroidea Latreille, 1807

Family Inoderbidae Shcherbakov et Emeljanov, fam.n.

TYPE GENUS. Inoderbe Shcherbakov et Emeljanov, gen.n.

DIAGNOSIS. Rather small planthoppers with membranous wings not folded over abdomen in repose, held laterally, and possibly rolling longitudinally. Tegmina and hindwings narrowed to base, hindwings small. Body and appendages covered with filamentous wax, dorsum with numerous wax plates (in females only?) producing copious wax strands, especially long on posterior abdomen. Tegmina: Precostal area wide, crossed by veinlets, not continued with apical cell series. Basal cell much elongated. Stigmal cell with submarginal pterostigma. CuA bifurcating close to basal cell, with 3 main branches, and terminations as numerous as those of $\mathrm{R}$ and $\mathrm{M}$ combined. Few crossveins in one gradate series. Clavus with scutellar angle subdued and shifted distally. Hindwings much smaller than tegmina, with small anal lobe; costal margin proximally with series of hamuli. Head compressed laterally, coryphe and metope with foliaceous lateral carinae, metope with small horn at midline; clypeus almost foliaceous, bicarinate; high preantennal carina with short subantennal branch. Antennae with scape and pedicel much elongate, compressed. Rostrum reaching beyond hind coxae.

How to cite this article: Shcherbakov D.E., Emeljanov A.F. 2021. Paradoxical derbid-like planthopper (Homoptera: Fulgoroidea) from Cretaceous Burmese amber // Russian Entomol. J. Vol.30. No.2. P.135-139. doi: 10.15298/rusentj.30.2.03 
Pronotum long, saddle-shaped, with broad lateral lobes, without high lateral, posterior, or inferior carinae. Mesonotum ecarinate, without scutellar grooves. Legs long and slender, with long hairs; hind tibia without lateral teeth, with asetigerous apical pecten. Abdomen narrow, with short, inverted Vshaped anterior tergites, apparently capable of raising its end with waxy tufts. Ovipositor short, with three pairs of subulate valvulae. Anal tube long, with arched side lobes.

COMPOSITION. Type genus.

COMPARISON. Similar to higher Derbidae in the wings held laterally, narrowed tegmina, small hindwings, laterally compressed head, hypertrophied antennae and presence of the high carina near antennae, but in derbids the precostal carina is narrow or undeveloped, the basal cell is small and $\mathrm{CuA}$ forked far from it in tegmina, the ovipositor is different, wax secretions are never so abundant, only the pedicel can be enlarged, and when the carina near the antenna is developed, it is subantennal, not preantennal. Similar to the Jurassic family Fulgoridiidae in the early forked $\mathrm{CuA}$ with three main branches in the tegmen, and to the Early Jurassic genus Eofulgoridium Martynov, 1937 of this family in the wide precostal area crossed by veinlets and not continued with the apical cell series, but in the latter family the basal cell is not elongated, the submarginal pterostigma is absent, and hindwings are not so small.

\section{Inoderbe Shcherbakov et Emeljanov, gen.n.}

TYPE SPECIES. I. rapunzel Shcherbakov et Emeljanov, sp.n. DIAGNOSIS. As for family.

COMPOSITION. Type species.

ETYMOLOGY. From Russian иной (different, other, alien) and Derbe; gender feminine.

\section{Inoderbe rapunzel Shcherbakov et Emeljanov, sp.n.} Figs 1-14.

MATERIAL. Holotype female PIN 5608/204 (head apex and fore knee polished away, right antenna missing) - Burmese amber Hukawng Valley, Kachin State, Myanmar; mid-Cretaceous (Albian-Cenomanian).

DESCRIPTION. Tegmen $6.5 \mathrm{~mm}$ long, $2.4 \mathrm{~mm}$ wide, elongate (2.7:1), narrow proximally, widest at nodus, acutely rounded at apex (at $\mathrm{M}$ terminations); anterior margin straight between base and nodus. Precostal area moderately wide, wider than costal area, with 5 irregularly spaced, slightly oblique veinlets; $\mathrm{C}$ joining $\mathrm{dSc}$ at nodus; vein running along anterior margin separated from it by narrow marginal membrane. Concave base of $\mathrm{Sc}(\mathrm{bSc})$ visible close to $\mathrm{R}+\mathrm{M}$ base Basal cell long and narrow, 1/5 tegmen length. Stigmal cell with lanceolate pterostigma along $\mathrm{dSc}$ and $\mathrm{RA}$, not reaching outer and distal edges of the cell. $\mathrm{R}+\mathrm{M}$ forked before arculus; $\mathrm{R}$ bifurcated at 0.3 tegmen length, fork narrow; RP fork and crossvein ir distal (in one tegmen RP 3-branched, with small extra fork). M bifurcated just beyond nodal level, 3-branched, pectinate backwards. CuA bifurcated just beyond arculus,
$\mathrm{CuA} 1$ with distal fork, $\mathrm{CuA} 2$ forked at $1 / 3$ tegmen length, pectinate forwards, with 4 terminations. $4-5$ crossveins (ir, $r$ $m, m-c u, 1-2$ icua) in oblique gradate series. $\mathrm{CuP}$ arched forwards. Claval veins united distally; common claval vein extremely short, entering commissural margin near acute claval apex; narrow marginal membrane before and just beyond claval apex. Marginal vein with dense erect hairs on both sides of tegmen, other main veins with sparse hairs. Membrane slightly infuscate, with pale fuscous pterostigma and small spots on veins and their terminations. Hindwing hyaline, $3.8 \mathrm{~mm}$ long, $1.6 \mathrm{~mm}$ wide, $\mathrm{x} 1.7$ shorter than tegmen. Costal margin with about dozen long crooked hamuli proximally, sinuate near midlength, with long coupling lobe bearing row of spinules; $\mathrm{R}$ against the lobe in hindwing and part of commissural margin in tegmen with similar spinules. $\mathrm{R}$ forked near coupling lobe; RA short; RP simple, reaching wing apex. $\mathrm{M}$ with distal fork. $\mathrm{CuA}$ forked at 0.3 wing length. Two crossveins (long $r-m$ and more proximal $m-c u$ ). Medial fold running close to $\mathrm{CuA}-\mathrm{CuA} 1$. CuP, Pcu and 1A simple; claval fold running from Pcu towards CuP. Anal area small, wing base narrow. Body $5.8 \mathrm{~mm}$ long (as preserved), slender, thorax and posterior abdomen $1.2 \mathrm{~mm}$ wide. Head narrow, eyes projecting (left eye partly preserved); coryphe (only posterior corner preserved) depressed, with lateral margins highly carinate; metope with short flattened horn at midline and nearly straight, foliaceous lateral carinae, narrowed before clypeus; clypeus nearly foliaceous, projecting trapezoidal in profile, with two high, undulating, close-set submedian carinae. Genae bearing high preantennal carina with short subantennal branch. Scape long, flattened, curved; pedicel long, reaching tegmen base at rest, in distal $2 / 5$ widened and covered with minute rounded sensory organs; base of flagellum small. Rostrum about $2.3 \mathrm{~mm}$ long, directed obliquely ventrally, with last segment about $1 / 4$ of its length. Pronotum long, tectiform, carinate along midline, with broadly rounded side lobes covered with wax hair. Mesoscutum rounded pentagonal, flattish, ecarinate, with pair of L-shaped wax areas (each with stem following course of lateral discal carina, and wide transverse arm) and wide depressions at sides of posterior margin not forming scutellar grooves. Mesopostnotum with pair of similar smaller wax areas. Metascutum diamond-shaped. Legs long, slender. Femora and outer side of tibiae and 1 st hind tarsomeres with long and very long erect hairs (much longer than leg diameter); inner side of fore and mid tibiae and 1st hind tarsomeres with short oblique setae; fore and mid tibiae and 1st and 2nd tarsomeres with ventroapical pectens of stout setae. Fore and mid tarsi long, 2nd tarsomere longer than 1st, 3rd slightly longer than 1st plus $2 \mathrm{nd}$. Hind tibia $2.0 \mathrm{~mm}$ long, without lateral spines, tibia and first two tarsomeres strongly swallow-tailed at apices, 1 st tarsomere longer than 2 nd plus 3 rd, tibia with $3+3$ broad asetigerous teeth, 1st tarsomere with 8 , 2nd with 9 teeth, mostly with dark acutellae, 1(2) outermost teeth at each side asetigerous. Claws long, proximally stout with 2 pairs of

Figs 1-12. Inoderbe rapunzel gen. et sp.n., Burmite, Cretaceous, holotype: 1 - habitus, laterodorsal; 2 - habitus, lateroventral; 3 head, anterolateral (arrow, preantennal carina); 4 - forebody, lateral; 5 - thorax and proximal abdomen, laterodorsal; 6 - left antenna, ventral; 7 - end of abdomen, lateroventral; 8 - left hind tarsus and apex of tibia, ventral; 9 - coupling lobe of right hindwing, ventral (arrow); 10 - hamuli of right hindwing, dorsal (arrows); 11 - left mid tarsus and proximal hind tibia, ventral; 12 - right fore tarsus and distal tibia, lateral (mirrored).

Рис 1-12. Inoderbe rapunzel gen. et sp.n., бирмит, мел, голотип: 1 - общий вид, сверху-сбоку; 2 - общий вид, снизу-сбоку; 3 голова, спереди-сбоку (стрелка - преантеннальный киль); 4 - передняя часть тела, сбоку; 5 - грудь и передняя часть брюшка, сверху-сбоку; 6 - левый усик, снизу; 7 - конец брюшка, снизу-сбоку; 8 - левая задняя лапка и вершина голени, снизу; $9-$ сцепочная лопасть правого заднего крыла, снизу (стрелка); 10 - сцепочные крючки правого заднего крыла, сверху (стрелки); 11 левая средняя лапка и проксимальная часть задней голени, снизу; 12 - правая передняя лапка и дистальная часть голени, сбоку (повёрнуто зеркально). 


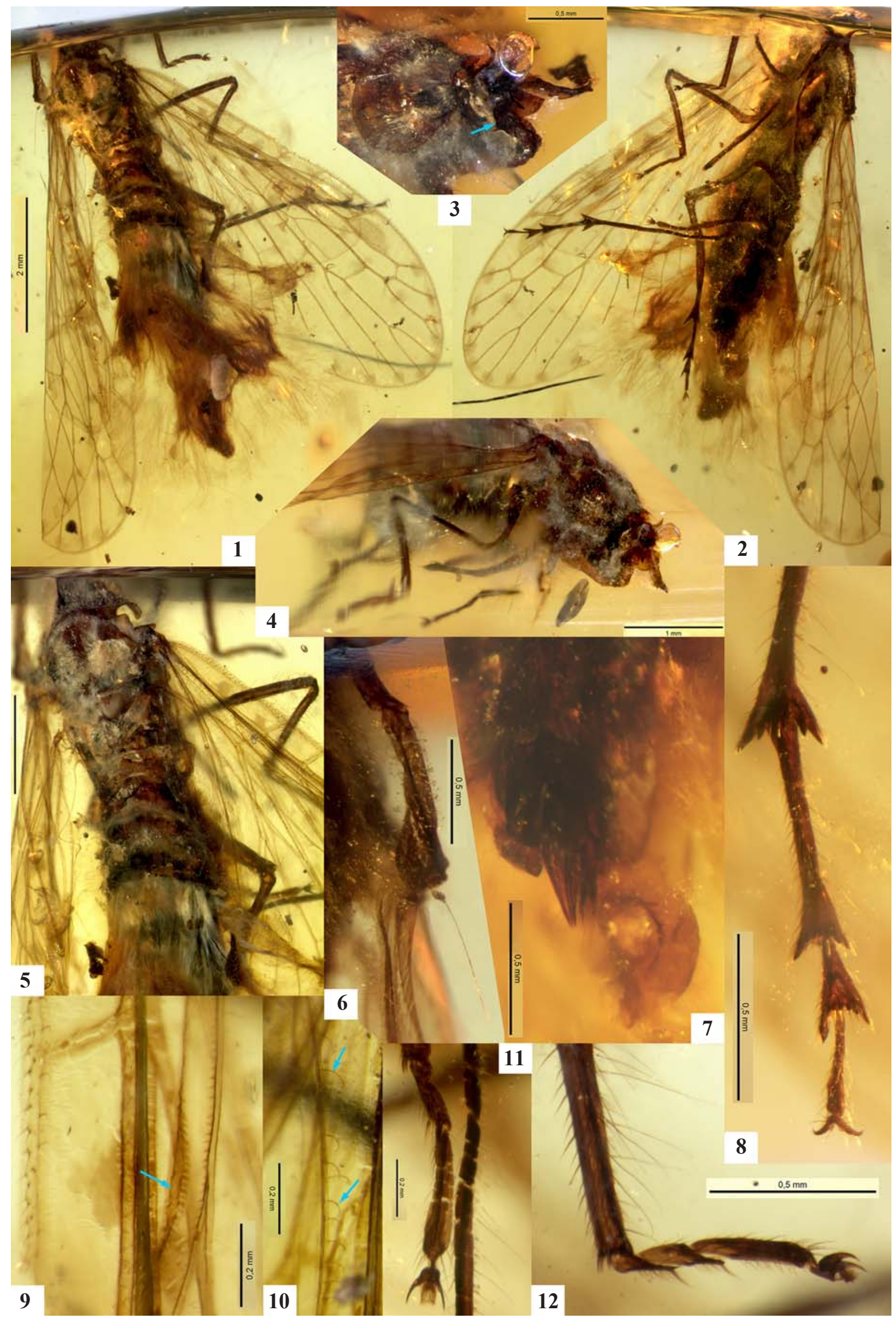


strong setae, apically crooked; arolium broad. Abdomen long, slender, widest about $1 / 4$ its length; anterior tergites short, raised, inverted V-shaped, separated by membranous spaces allowing to lift up posterior abdomen with wax tufts. Last pregenital tergite with small subtriangular side lobes. Ovipositor short, with two apposed pairs of subulate inner valvulae and one dorsal, forceps-like pair of somewhat longer, acute outer valvulae. Anal tube long, narrow basally, with crescent-shaped lateral lobes distally. Nearly all body parts, including scape and proximal pedicel, tegulae, wings, and legs up to tarsi, sparsely or densely covered with milky whitish wax filaments of various lengths. Distinct wax plates on mesoscutum and mesopostnotum (most of wax apparently removed from thorax) and abdominal tergites, those on middle tergites forming rows of 8 or 10 small rounded plates. Wax strands on posterior abdomen up to $3.6 \mathrm{~mm}$ long, slightly curly, white to golden reddish, forming somewhat tripartite plumage. Body dark brown, extremities nearly black.

ETYMOLOGY. Rapunzel, fairytale maiden with very long golden hair, imprisoned in a tower; noun in apposition.
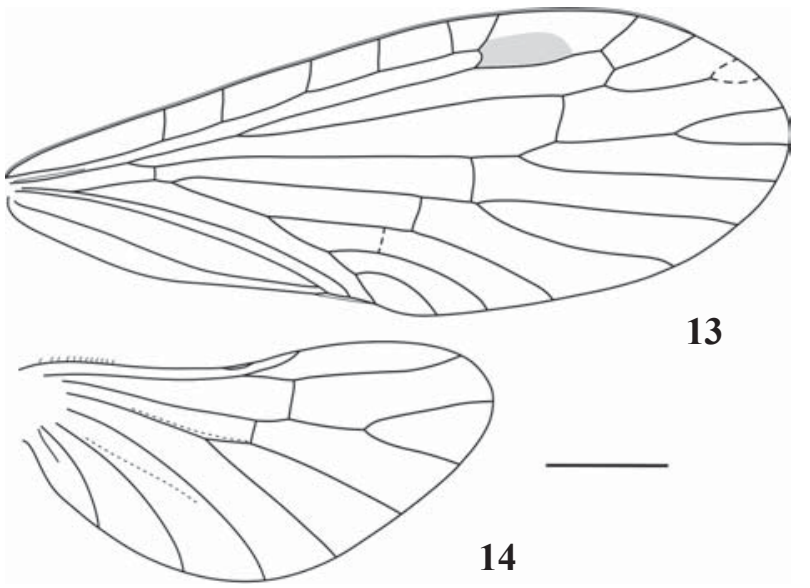

13

Figs 13-14. Inoderbe rapunzel gen. et sp.n., Burmite, Cretaceous, holotype, venation: 13 - tegmen (dashed line, extra fork of right tegmen and extra crossvein of left tegmen); 14 - hindwing (dashed line, medial and claval folds). Scale bar: $1 \mathrm{~mm}$.

Рис. 13-14. Inoderbe rapunzel gen. et sp.n., бирмит, мел, голотип, жилкование: 13 - переднее крыло (пунктиром дополнительный развилок правого крыла и лишняя поперечная левого крыла); 14 - заднее крыло (пунктиром - медиальная и клавальная складки). Масштабная линейка: 1 мм.

\section{Discussion}

The new planthopper bears superficial resemblance to some higher groups of the extant family Derbidae. The earliest, very primitive derbids still similar to Achilidae were recently described from Burmese amber [Emeljanov, Shcherbakov, 2020], whereas the higher tribes of Derbidae appear in the fossil record much later, in the Eocene (Otiocerini), Miocene (Derbini), or Quaternary (Zoraidini); other higher tribes are still unknown as fossils. Reduction of scutellar grooves and the scutellar angle of the clavus, as well as the abundant wax coat of the dorsal thorax and abdomen in the new genus, indicate that these insects did not fold their wings over the abdomen in repose, but held them sideways or spread in a V above the body, like Derbini, Rhotanini, Zoraidini and Sikaianini. The hindwings of the fossil are much smaller than the forewings, again like in these derbid tribes. The wings at one side of the holotype are rolled longitudinally, the hindwing being encircled by the tegmen, and if this was their natural resting position, then the new genus is similar in this habit to yet another tribe of Derbidae, the extant Dawnarioidini.

The head of the new planthopper is derbid-like compressed laterally, with foliaceous lateral carinae of the coryphe and metope, almost foliaceous clypeus with two high submedian carinae, antennae with both scape and pedicel much elongated, and the high preantennal carina with a low subantennal branch. However, in known Derbidae the scape is never enlarged, and when the carina or lobe near the antenna is developed, it is subantennal, not preantennal. Hypertrophy of the pedicel, and development of subantennal lobes and high lateral, posterior, or inferior carinae on the pronotum (sometimes forming a kind of funnel around the pedicel) in higher derbids presumably improve sensory abilities of their antennae [Emeljanov, 1996]. The new genus is also dissimilar to Derbidae in other basic characters (see below).

The antennae of the fossil are hypertrophied in a way similar to some primitive Delphacidae (Ugyopinae, Asiracinae, Vizcayini), i.e. both scape and pedicel are elongated (in Derbidae only the pedicel). However, the new genus lacks any diagnostic characters of Delphacidae.

The tegmina of the new fossil show the $\mathrm{CuA}$ forked proximally with three main branches and as many terminations as on $\mathrm{R}$ and $\mathrm{M}$, similar to the Jurassic family Fulgoridiidae, and also the wide precostal area crossed by veinlets and not continued into the apical cell series, like in the Early Jurassic genus of this family, Eofulgoridium Martynov, 1937. In the extant planthopper groups, the $\mathrm{CuA}$ is not so richly branched compared to R plus $\mathrm{M}$, and the precostal area, if wide and cross-veined, is continued into the apical cell series. However, in Fulgoridiidae the basal cell is not elongated, the submarginal pterostigma is absent, and hindwings are not so small. Inoderbe gen.n. is apparently the first planthopper with a wide cross-veined precostal area described from the Cretaceous.

The rich waxy plumage of the new genus somewhat resembles those of large planthoppers, especially Fulgoridae [O'Brien, 2002]. The wax coating of Homoptera probably protects them from rain, UV radiation and predators and prevents contamination with honeydew. Females are more likely to produce large quantities of wax than males, often smearing wax over egg deposition sites, and in adult Fulgoroidea wax plates are developed only in females [O'Brien, Wilson, 1985; Lucchi, Mazzoni, 2004; Emeljanov, 2009].

Some plants, invertebrates and frogs preserved in Burmese amber are indicative of the presence of humid tropical forests [Xing et al., 2018; Rosa, Melo, 2021]. The derbid-like wing proportions and resting position and rich wax garment of the new genus can be considered anti-wetting adaptations. The same is true of the 
longitudinal wing rolling, postulated to be a wingstrengthening device for adaptation to life in rain forests [O’Brien, 1982].

The new genus showing a previously unknown combination of characters is separated into a new family, which appears to be descended from Fulgoridiidae. It is one more family of the primitive group related to fulgoridiids, or pre-cixioid group [Shcherbakov, 2007], which also includes Perforissidae, Jubisentidae, Mimarachnidae, Dorytocidae, Neazoniidae, with deeply forked and/or richly branched $\mathrm{CuA}$ in the tegmen, and often setigerous hind tibial pectens.

Several characters of Inoderbidae foreshadow traits that are fully developed in Derbidae. Inoderbids, which were later replaced by true derbids, can be seen as an example of inadaptive group (the term of Vladimir Kovalevsky [1873-1874]).

Acknowledgements. We are grateful to Alexey Bashkuev for bringing this fossil to our attention, and to Roman Rakitov (both PIN) for valuable comments. The study is performed in the framework of the Russian State Research project no. AAAA-A19-119020690101-6.

Competing interests. The authors declare no competing interests.

\section{References}

Emeljanov A.F. 1996. On the system and phylogeny of the family Derbidae (Homoptera, Cicadina) // Entomol. Rev. Vol.75. No.2. P.70-100.

Emeljanov A.F. 2009. Evolutionary transformations of abdominal wax-plates in the larvae of the Fulgoroidea (Homoptera, Cicadina) // Entomol. Rev. Vol.89. P.1035-1054. https://doi.org/ $10.1134 / \mathrm{S} 0013873809090048$

Emeljanov A.F., Shcherbakov D.E. 2018. The longest-nosed Mesozoic Fulgoroidea (Homoptera): A new family from mid-Cretaceous Burmese amber // Far East. Entomol. Vol.354. P.1-14 https://doi.org/10.25221/fee.354.1

Emeljanov A.F., Shcherbakov D.E. 2020. The first Mesozoic Derbidae (Homoptera: Fulgoroidea) from Cretaceous Burmese amber // Rus. Entomol. J. Vol.29. No.3. P.237-246 https://doi.org/ 10.15298/rusentj.29.3.02

Fu Y., Huang D. 2021. New mimarachnids in mid-Cretaceous amber from northern Myanmar (Hemiptera, Fulgoromorpha) // Cretac. Res. Vol.119. 104682 https://doi.org/10.1016/j.cretres.2020. 104682.

[Kovalevsky V.] Kowalevsky W. 1873-1874. Monographie der Gattung Anthracotherium Cuv. und Versuch einer natürlichen Classification der fossilen Hufthiere// Palaeontographica. Bd.22. H.3-5. S.125-347.

Lucchi A., Mazzoni E. 2004. Wax production in adults of planthoppers (Homoptera: Fulgoroidea) with particular reference to Metcalfa pruinosa (Flatidae) // Ann. Entomol. Soc. Am. Vol.97. P.1294-1298 https://doi.org/10.1603/00138746(2004)097[1294:WPIAOP]2.0.CO;2
Luo C., Jiang T., Szwedo J., Wang B., Xiao C. 2020. A new planthopper family Katlasidae fam. nov. (Hemiptera: Fulgoromorpha: Fulgoroidea) from mid-Cretaceous Kachin amber // Cretac. Res. 104532 https://doi.org/10.1016/j.cretres.2020.104532

Luo C., Wang B., Jarzembowski E.A. 2021. A bizarre planthopper nymph (Hemiptera: Fulgoroidea) from Mid-Cretaceous Kachin amber // Insects. Vol.12. 318 https://doi.org/10.3390/insects 12040318

O'Brien L.B. 1982. Two Neotropical derbid genera with observations on wing rolling (Fulgoroidea, Homoptera) // Fla. Entomol. Vol.65. P.306-321.

O'Brien L.B. 2002. The Wild Wonderful World of Fulgoromorpha // Denisia. Vol.4. P.83-102.

O'Brien L.B., Wilson S.W. 1985. Planthopper systematics and external morphology // L.R. Nault, J.G. Rodriguez (eds.). The Leafhoppers and Planthoppers. New York: John Wiley and Sons. P.61-102.

Olmi M., Chen H.Y., Shih C., Müller P., Capradossi L., Ren D., Perkovsky E.E., Guglielmino A. 2021. New species of Hybristodryinus Engel (Hymenoptera, Dryinidae) from mid-Cretaceous amber of northern Myanmar, with notes on their possible hosts // J. Hymenopt. Res. Vol.81. P.43-55. https://doi.org/ $10.3897 / \mathrm{jhr} .81 .57792$

Rosa B.B., Melo G.A. 2021. Apoid wasps (Hymenoptera: Apoidea) from mid-Cretaceous amber of northern Myanmar // Cretac. Res. Vol.122. 104770. https://doi.org/10.1016/j.cretres.2021.104770.

Ross A.J. 2021. Supplement to the Burmese (Myanmar) amber checklist and bibliography, 2020 // Palaeoentomology. Vol.4. No.1. P.057-076. https://doi.org/10.11646/palaeoentomology.4.1.11

Shcherbakov D.E. 2000. The most primitive whiteflies (Hemiptera; Aleyrodidae; Bernaeinae subfam. nov.) from the Mesozoic of Asia and Burmese amber, with an overview of Burmese amber hemipterans // Bull. Nat. Hist. Mus. London (Geol.). Vol.56. P.29-37.

Shcherbakov D.E. 2007. An extraordinary new family of Cretaceous planthoppers (Homoptera: Fulgoroidea) // Rus. Entomol. J. Vol.16. P.139-154.

Shcherbakov D.E. 2020. The earliest fully brachypterous auchenorrhynchan from Cretaceous Burmese amber (Homoptera: Fulgoroidea: Jubisentidae) // Rus. Entomol. J. Vol.29. P.6-11 https:// doi.org/10.15298/rusentj.29.1.02

Song Z.S., Xu G.H., Liang A.P., Szwedo J., Bourgoin T. 2019. Still greater disparity in basal planthopper lineage: A new planthopper family Yetkhatidae (Hemiptera, Fulgoromorpha, Fulgoroidea) from mid-Cretaceous Myanmar amber // Cretac. Res. Vol.101. P.47-60 https://doi.org/10.1016/j.cretres.2019.03.023.

Song Z.S., Zhang C.L., Xi H.Y., Szwedo J., Bourgoin T. 2021. First record of adult Dorytocidae — Dorytocus jiaxiaoae Song, Szwedo \& Bourgoin sp. nov. (Hemiptera: Fulgoromorpha: Fulgoroidea) from mid-Cretaceous Kachin amber // Cretac. Res. 104863 https://doi.org/10.1016/j.cretres.2021.104863

Szwedo J. 2004. Niryasaburnia gen. nov. for 'Liburnia' burmitina Cockerell, 1917, from Cretaceous Myanmar (Burmese) amber (Hemiptera, Fulgoromorpha: Achilidae) // J. Syst. Palaeontol. Vol.2. P.105-107 https://doi.org/10.1017/S1477201904001154.

Westerweel J., Roperch P., Licht A., Dupont-Nivet G., Win Z., Poblete F., Ruffet G.; Swe H.H., Thi M.K., Aung D.W. 2019. Burma Terrane part of the Trans-Tethyan arc during collision with India according to palaeomagnetic data // Nat. Geosci. Vol.12. P.863868 https://doi.org/10.1038/s41561-019-0443-2

Xing L., Stanley E.L., Bai M., Blackburn D.C. 2018. The earliest direct evidence of frogs in wet tropical forests from Cretaceous Burmese amber// Sci. Rep. Vol.8. P.1-8 https://doi.org/10.1038/ s41598-018-26848-w 